This is an Accepted Manuscript of an article published by Taylor \& Francis in Critical Military Studies on 13/11/19, available online:

https://www.tandfonline.com/doi/full/10.1080/233374886.2019.1687997 


\section{Freedom of Information Legislation and the Democratic Oversight Narrative}

\section{Peter Finn*}

Kingston University, London, United Kingdom

ORCID: 0000-0003-3341-1079

Twitter:@Pete_D_Finn

*Contact Peter Finn: p.finn@kingston.ac.uk

Acknowledgements: An earlier version of this paper was presented at the 2018 BISA conference in a panel on methodological challenges and opportunities. I am grateful for the feedback received. I am also thankful for the feedback of three anonymous reviewers. 


\title{
Freedom of Information and the Democratic Oversight Narrative
}

\begin{abstract}
Oversight of national security operations is often presented as vital to ensuring military and intelligence personnel of democratic states abide by the rule of law. Collectively, such portrayals place stock in what this paper conceptualises as the democratic oversight narrative. In the US and the UK, freedom of information legislation is presented as a tool giving the democratic oversight narrative form in the real world. This occurs, it is argued, because such legislation allows those (such as legislators and the media) responsible for the oversight of national security access to information about said operations in order to mediate between citizens and states. In recent years, documents containing implicatory information have been released by the US and the UK, but often only after prolonged legal cases and significant obstruction by both states. Drawing on documents pertaining to processes set in motion by the American Civil Liberties Union and the UK All Party Parliamentary Group on Extraordinary Rendition focused on obtaining information about War on Terror era detainee abuse, this paper argues that those engaged in oversight of US and UK national security operations are faced with overly burdensome barriers and impediments when seeking the disclosure of potentially implicatory information that should, via the use of oversight tools such as freedom of information processes, legitimately be released. These barriers and impediments arise, it is shown, because both states are able to counter oversight by drawing on an opposing set of tools to stop (or at least stall) the release of such information.
\end{abstract}

Keywords: national security, freedom of information, oversight, democracy

Disclosure Statement: I have no conflicts of interests with relation to this paper

\section{Introduction}

A key plank of arguments utilised to explain the supposed adherence to the rule of law by the United States (US) and the United Kingdom (UK) is that, as democracies, they are subject to oversight. Linking to the international realm, Darius Rejali summarises that national security bureaucracies, such as militaries and intelligence services, within democracies 'are constrained by constitutions', judges, internal inspector generals, the 
media and civil society (Rejali 2007, Loc.612). Such constraints are portrayed as key to a virtuous circle holding individuals and democratic states to account when laws are violated. Thus, upholding the rule of law and allowing 'people to predict the consequences of their actions' (Maravall and Przeworski 2003, 2). An important way accountability is achieved, it is posited, is via the 'flow of information' (Institute for Democracy and Electoral Assistance 2014) that ensures 'democratic leaders can never be entirely free from a commitment to truth-telling' (Shapiro 2003). As such, though there is an obvious need to exempt some information from public release (some for defined periods, some permanently) and allow national security bureaucracies freedom to respond to evolving threats, democratic 'values', it is argued, are 'endangered' by unjustified secrecy and/or a dearth of oversight (Thomas 2019, 1-2). Collectively this paper labels this line of thought the democratic oversight narrative.

A tool that should give the democratic oversight narrative form in the US and the UK is freedom of information legislation. In short, such legislation allows individuals (whether citizens of either state or not) and organisations the ability to request information (subject to restrictions) held by parts of both states. A process said to increase 'accountability', grow 'trust in government' (Denham 2018) and prevent an 'accountability deficit' developing (Ackerman and Sandoval-Bellesteros 2006, 87). Reflecting this, regulations state that restrictions should not be used to conceal illegality, incompetence or embarrassment (UK Information Commissioner's Office 2019; US Government 2015). Critics have critiqued the administration of freedom of information processes in both states. It has been argued, for instance, that a UK ministerial veto gives the executive too much power (Brake 2016), whilst political game playing that has led to differences between the responses of US presidential administrations to requests for information have been decried (Wagner 2017, 389). Considering both states 
comparatively, Laura Donohue argues that, despite constitutional, political and judicial variations, a simplistic 'dichotomy' discursively locating information pertaining to national security within the parameters of a security Vs freedom rubric prevails in both instances. Donohue demonstrates this leads to overly zealous information and speech restrictions that create 'profound' costs not captured by the rubric (Donohue 2008, 132,332). Similarly, Owen David Thomas has shown that, while UK freedom of information legislation captures the 'harm' associated with too much transparency, it fails to capture the 'harm' connected to the 'securitization of secrecy' arising from the 'presumption that disclosure' always contains a 'potential threat' (Thomas 2019, 3,5,7). In short, Thomas illustrates that the 'insecurity of secrecy is not recognized' (Thomas $2019,9)$.

Reflecting Donohue and Thomas, this article highlights barriers and impediments to the contribution that freedom of information legislation can make to the realisation of the democratic oversight narrative, as well as the harm (costs) that can arise from such barriers and impediments. This harm is important for two reasons. Firstly, freedom of Information legislation has, in the first instance, a very low barrier to entry, in that anybody can request information at no (or very low) cost in both the US and the UK. As will become clear, significant barriers do arise if one chooses to challenge non-disclosure. However, initially at least, freedom of information requests, as an oversight tool, are dispersed to all engaged in oversight of the US and UK states, in the arena of national security or otherwise. Meaning the administration of freedom of information processes can impact all those engaged in the oversight of either state. Secondly, and as we shall see, there are significant barriers and impediments to the sound administration of other tools available to those engaged in national security oversight such as legislative investigations and legal proceedings. Meaning harm related to the administration of 
freedom of information processes should be viewed as compounding harm arising from impediments to other such tools rather than in isolation.

Operating comparatively, this article contributes to the broader freedom of information literature in the context of both states, as well as related comparative literature. In doing, it aims to illuminate a disconnect between the ideals captured by the democratic oversight narrative and a process giving it form. It does so by focusing on freedom of information requests pertaining to US and UK War on Terror era detainee abuse. In doing it provides discussions of two hitherto under-considered case-studies: freedom of information requests, and related legal proceedings, lodged with the US Government by the American Civil Liberties Union and requests, and related legal cases, lodged with the UK Government by an All Party Parliamentary Group. This paper evolves across four sections. Firstly, the democratic oversight narrative concept is fleshed out and problematized. Secondly, the broader information classification and control systems of both states are introduced. Thirdly, US and UK freedom of information processes are discussed. In these three sections, material pertaining to national security is privileged. Together, sections two and three provide an understanding of the main structures and strictures of classification and freedom of information legislation in both states. Thus, informing discussions of the two case-studies, which are considered last.

This paper engages with the puzzle of judging government responses to freedom of information requests in the arena of national security. It innovates in two ways. Conceptually, it introduces the democratic oversight narrative as a means of capturing the faith that oversight of the national security operations of democratic societies helps ensure adherence to the rule of law. Importantly, while the author does not deny oversight does, on occasion, do this, the idealized version of the democratic oversight narrative is problematized. Empirically, it engages with two hitherto under-explored case-studies to 
demonstrate that, while the minutiae may differ, a similar disconnect from the idealized version of the democratic oversight narrative is present in both cases. In short, this paper argues that those engaged in oversight of US and UK national security operations are faced with overly burdensome barriers and impediments when seeking the disclosure of potentially implicatory information that should, via the use of oversight tools such as freedom of information processes, legitimately be released. These barriers and impediments arise, it is shown, because both states are able to counter oversight by drawing on an opposing set of tools to stop (or at least stall) the release of such information. This situation creates three interrelated harms. Firstly, those, such as former detainees, impacted by national security policies, and those close to and representing them, are not granted access to information about their treatment. Secondly, those engaged in oversight are similarly deprived of information. Finally, US and UK failures to adequately engage with oversight procedures will likely undermine faith in future claims and behaviour. As we shall see, these harms can have real-world implications rather than being purely theoretical.

\section{Democratic Oversight Narrative}

Conceptually, the democratic oversight narrative is defined as a collective faith that oversight, whether internal or external to a state, of national security operations of democracies help maintain the primacy of the rule of law. Such oversight, it is argued, 'enhance[s] the legitimacy of [...] institutional structures' (Curtin and Meijer 2006, 111) by ensuring 'information about' a government's 'internal characteristics' (Ball 2009, 298) are available to citizens following 'mediation' via oversight bodies (Curtin 2014, 688-9). Such mediation should resolve 'the conflict between democratic oversight and executive secrecy by having citizens delegate' oversight (Curtin 2014, 688). Thus maintaining 'trust [...] necessary for the functioning of democracies' (Gurria 2016) by creating 'active' 
citizens who can 'sanction' elected governments by 'ousting' those who perform poorly (Manin, Przeworski and Stokes 1999, 10; Mittchell in US Geospatial Intelligence Foundation 2016, 32).

Subscribers to the democratic oversight narrative can be found, among other places, in the academy, the judiciary, government and civil society. Crucially, subscribers do not deny the arena of national security poses distinct oversight challenges (Colaresi 2014, 3-9). Nor do they suggest all information related to national security should be made public or provided to oversight bodies (Sagar 2013, 80-102). Yet, they, like the author, would, to varying degrees, subscribe to Thomas' assertion that democratic values are 'endangered' if unnecessary 'concealment', and attendant oversight decline, occur (Thomas 2019, 2), Along with the claim that, '[i]n contemporary liberal democratic contexts $[\ldots]$ few would accept a situation where oversight of intelligence resided solely' with 'the executive' (Gill and Phythian 2018, 19). Indeed, as Andrew Defty notes, the post-Nixon (and post-cold War) era has seen a 'near universal acceptance of the need for democratic oversight' and a side-lining of the idea 'legislative scrutiny of intelligence is special' (Defty 2019a, 24). All told, oversight is portrayed as fostering a virtuous circle leading to the 'contingent renewal' of democracy, legitimate government and adherence to the rule of law (Manin, Przeworski and Stokes 1999, 10).

Oversight captured by the democratic oversight narrative may occur internally, within bodies such as legislative committees and internal inspector generals, or involve external oversight actors such as the media (sometimes labelled a fourth branch of government), human rights organisations, whistle-blowers or journalists. In an interesting formulation, Richard Aldrich and Daniela Richterova have labelled external oversight 'ambient' oversight. Such ambient oversight is defined by actors, such as journalists and human rights organisations, working externally to a state that are able to work in formal 
and informal networks with the ability to 'collaborate on lengthy investigations', that, in some instances, ensure the 'secret state feels increasingly obliged to explain itself' (Aldrich and Richterova 2018, 1005-6). Relatedly, Aldrich and Christopher Moran posit the networked nature of modern societies is feeding a broader trend challenging the ability of states to maintain control of information in the face of a 'tsunami of electronic transparency' (Aldrich and Moran 2018, 2-13). Whether internal or ambient, oversight bodies can draw on varying formulations of an overlapping and interconnected set of tools such as legal procedures (with the judiciary sometimes portrayed as an independent actor), hearings and freedom of information requests (Arendt 1973, 41; Deeks 2013; Kelly 2012, Loc.3185; UK Judicial Office 2015). Debates about the shape oversight should take, and how to improve current formulations, abound (Joseph 2011, 187-93; Kitrosser 2008, 1050). Yet, the democratic oversight narrative encapsulates a faith that, if formulated correctly, oversight provides an effective check on executive power.

Given their 'self-image' as democratic 'bastion[s] of human rights and the rule of law', the US and the UK appear fertile ground for internal and ambient oversight bodies to give the democratic oversight narrative form by continually mediating between national security bureaucracies and citizens (Kelly 2012, Loc.3189). Yet, a disconnect exists between the idealized version of the democratic oversight narrative and the reality of oversight of US and UK operations. Tobias Kelly, for instance, demonstrates that, because many inputs affect policy, 'the shame of torture easily dissipates', further showing that a focus on shaming and 'transparency create space' for the deployment of discursive tropes and political game-playing via an 'endless deferral onto even more policies and protocols' (Kelly 2012, Loc.3628-29). Focusing on judicial oversight, Norman Ornstein \& Thomas Mann argue US congressional oversight 'virtually' collapsed post-9/11 (Mann and Ornstein 2006, 68). Likewise, the last 6 years has seen 
prolonged periods following two general elections, which together accumulate to almost a year, when the UK Intelligence and Security Committee (ISC) did not operate because of delays to committee appointments, as well as government failures, which contravene a memorandum of understanding with the UK government, to respond to the committee's work in a timely manner, and sometimes not at all (Defty 2019a, 30,32; Defty 2019). As such, the UK intelligence community was bereft of legislative oversight for prolonged periods, while the UK government failed in its duty to respond to the committee's work. Discussing US courts, meanwhile, Wayne McCormack argues deference to the executive has seen the judiciary 'ceding power' since 2001 (McCormack 2014, 333,401). Similarly, Ruth Blakeley and Sam Raphael contend that, following the UK government's suspension of law, the importance of judicial review of detainee abuse has been reduced (Blakeley and Raphael 2017). Discussing the media, W. Lance Bennett et al found the US media's framing of the Abu Ghraib scandal (which occurred after photos taken in autumn 2003 documenting abuse by US personnel at a detention site in Iraq named Abu Ghraib became public) demonstrated 'limits' to 'press independence' because, despite evidence to the contrary, the media adopted the official narrative that the scandal represented abuse by a few errant soldiers, rather than the plausible alternative it reflected torture as policy (Bennett, Lawrence and Livingston 2005, 482; Remick 2004, IX-XIX). Likewise, UK journalist Robert Fox argues UK media coverage of the invasion of Iraq was characterised by a ‘lack of editorial question' (Fox 2013).

This section has documented the existence of the democratic oversight narrative, and the faith placed in it with relation to US and UK operations. As importantly, however, we have seen how this collective faith should, at least on occasion, be questioned: with powerful impediments, such as government failures to respond to legislative committees and an unquestioning acceptance of official narratives, contributing to a reduction in the 
ability of oversight bodies to successfully mediate. This is not to argue oversight never leads to accountability and does not, on occasion, contribute to the rule of law's primacy. Indeed, this paper evidences this occurs on occasion. Yet, it also documents that oversight bodies and tools, often stymied by overly burdensome barriers and impediments, regularly appear to fall short, with real world harms such as the deflection of responsibility for wrongdoing, reductions in the role of judicial and legislative review and the reductions in public understanding arising from the adoption of singular, officially shaped, narratives about wrongdoing occurring. With these harms in mind, we now turn to the consideration of US and UK classification systems.

\section{Information Classification Systems}

Contemporary freedom of information processes do not exist in a vacuum. Indeed, they slot into broader systems for the management, classification, release and restriction of information. As such, before freedom of information is zeroed in on, a review of broader US and UK classification and control systems, especially as they pertain to national security, is in order. The US system is dealt with first, followed by the UK. The section closes with some reflections on such systems in a democratic context. With a tendency towards secrecy highlighted.

The contemporary US national security classification system is exceedingly complex. Present classifications are based on a rubric introduced in 1951, whilst oversight structures trace their roots to post-Nixon era reforms (Johnson 2018, 101-130; Truman 1951). Reflecting international norms, this system contains three broad levels of classification related to information's 'significance': confidential, secret and top secret, (US Government 1982). Each classification level contains further categories, with separate protocols for intelligence information. Moreover, handling caveats, which can cut across categories and could, for instance, restrict access to US citizens, and 
'dissemination' controls are also used (US Defense Department 2013, 8; US Under Secretary of Defense 2005). Each classification level, handling caveat, dissemination control, along with compartments and sub-compartments within further silos such as Special Access Program systems, ensure what Peter Galison labels 'augmented secrecy' defines a system that saw up to eight billion pages of information classified from 19782004 (Electrospaces 2013; Galison 2004, 230-1). But, in what could be called a 'double' secret in that it is impossible to even know what is known, so shrouded in secrecy are the inner workings of this system, its 'deeper parts [...] are classified' (Electrospaces 2013; Aldrich and Moran 2018, 5).

The UK similarly augments information into three broad categories: official, secret and top secret (UK Cabinet Office 2013, 4). Contemporary UK oversight, meanwhile, has evolved since the late-1980s, with intelligence bodies (MI5, MI6 and GCHQ) acknowledged and legislated for and intelligence oversight placed under the ISC's purview (Intelligence and Security Committee 2019; UK Parliament 1989; UK Parliament 1994). Though a notable lacuna exists for UK Special Forces oversight and, as already seen, there have been problems with the ISC's continuity of operation and government failures to respond to its work on occasion (Karlshoej-Pedersen and Walpole 2018). Within categories, further classifications can be placed on documents via the use of a 'Caveat' or 'Special Handling Instructions' used to signify 'further controls' (UK Cabinet Office 2018, 30). Finally, important sections of the UK's national security apparatus are covered by a policy, known as neither confirm nor deny, adopted by governments of all political hues, that sees the UK refusing to comment on Special Forces or intelligence bodies (Lewis 2013; Norton-Taylor 2014).

At this point, it is likely worth re-iterating that there is information pertaining to national security that states should legitimately keep secret, with the finer points of 
nuclear programs and troop movements being two illustrative examples. In fact, as the MI5 website correctly notes, secrecy can be 'essential' for such bodies 'to perform [...] effectively' (MI5 2015). However, mirroring Thomas and Defty, David Vincent suggests that, for democracy to work, there is a need for citizens to both 'trust' certain information is held safely by the state, whilst not feeling secrets are being unduly kept (Vincent 1998, VII, 328). Yet, as Max Weber suggested, bureaucratic interest in keeping information secret can go 'far beyond' what is needed for 'functional' purposes. More to the point, he highlighted the "'official secret'" concept is ripe for political game-playing designed to protect the 'power' of bureaucracies against the intervention of politicians steeped in informational 'ignorance' (Weber 2009, 232-4). Similarly, Sissela Bok, though accepting certain restrictions, argues that 'when power is joined to secrecy [...] the danger of [..] abuse [...] increases', therefore creating the need for whistle-blowers to act as guardians against 'threats to public interest shielded by practices of secrecy' (Bok 1989, 110). Elsewhere, Rahul Sagar has argued that, if an effort is made to change policy and reduce the harm of a leak prior to leaking, then leakers, especially if they identify themselves, can provide a safety valve against wrongdoing (Sagar 2013, 127-80). Offering a way forward, Bok urges a reduction in 'collective secrecy', and thus the political game-playing and discursive tropes that can both feed into and strengthen it, 'to permit the normal channels of public inquiry [and mediation] to replace [...] whistleblowing and leaking' (Bok 1989, 228).

Yet, the collective strength of information augmentation related to US and UK national security operations means that, often from its creation, such information is held in a manner that, deliberately or not, gives weight to practices of collective secrecy at the expense of mediating tools of public inquiry. Thus, creating an insecurity of nondisclosure via potentially overly burdensome barriers and impediments. A state of affairs 
which, in line with Weber, appears likely to lead to the problem of 'overclassification' highlighted by Hannah Arendt who, while discussing the Pentagon Papers, illustrated how an overabundance of classified material can become too burdensome for those who have access to it to digest, even if they have the will to do so (a will Arendt persuasively argues appears absent), and, as importantly, prevents such material from being analysed and critiqued by those without requisite access (Arendt 1973, 29-30). As such, it is important to consider how such overclassification, along with broader information augmentation, may negatively impact, and/or compound problems arising from, the administration of mediating tools such as freedom of information. A task to which this paper now turns. As we shall see, the administration of said processes are likely more reflective of Arendt, Weber and Bok's observations about power and secrecy and Donohue and Thomas' warnings about the costs incurred by the privileging of the security Vs freedom rubric than the picture provided for in the idealised version of the democratic oversight narrative.

\section{Freedom of Information Processes}

A law impacting the US classification system is the 1967 US Freedom of Information Act (USFOIA) (US Justice Department, 2015). This act allows individuals (US citizens or otherwise) and organisations to request information held by the US Federal Government at no initial cost (US Justice Department, 2015a). Information released under the USFOIA is subject to nine exemptions, three exclusions, information classifications and restrictions. The exemption most relevant here relates to national security. Of the USFOIA's three exceptions, one, related to classified foreign intelligence, terrorism and counterintelligence material held by the Federal Bureau of Investigation, is most likely to impact this paper's subject matter (US Justice Department, 2015b). Following 9/11, new USFOIA exempt categories, such as 'sensitive security 
information', began to be used across the US government (Feinberg 2004; US Department of Homeland Security 2006, 10). However, as already noted, federal regulations make clear that USFOIA procedures, along with the broader US classification system, should not be used to cover up wrongdoing or incompetence (US Government 2015).

Restrictions of relevance include a 1984 law allowing the Central Intelligence Agency (CIA) to exempt operational files from the USFOIA's strictures (US Government 1984). A second relevant restriction, the Glomar response, pertains to records whose existence is classified. This response allows agencies to refuse to confirm or deny the existence of requested records (Sagar 2013, 75-6). Both these restrictions have been used with relation to Guantánamo detainees. The CIA, for example, stated it would not release documents related to enhanced interrogation techniques used on one Guantánamo detainee as they were 'in operational files' (CIA in Worthington 2011). Meanwhile, the US government successfully argued it need not confirm nor deny the existence of intercepts of conversations between Guantánamo detainees and their legal representatives. Intercepts that, if they exist, would impinge on the idea of attorney client privilege (Meyerowitz 2008). Though the citing of restrictions may, in certain circumstances, be valid responses, the two examples pertaining to operational files and the Glomar response above help illuminate an important harm, regardless of whether the use of these restrictions was legitimate in these cases, that can arise from their use: namely that they may also prevent information pertaining to those seeking redress from entering the public domain. As importantly, they illustrate that the USFOIA is part of the broader US classification system, with the information that is, and is not, released affected by preexisting classifications as much as it is by the USFOIA itself. 
The 2000 UK Freedom of Information Act (UKFOI) allows anyone (UK citizens or otherwise) to request information at no initial cost (UK Parliament 2000). Of these, nine are absolute, meaning disclosure is barred, whereas the rest are qualified, denoting a public interest argument may be taken into account when disclosure is considered (Birkinshaw 2010, 314). Qualified exemptions are split into two further categories, class based, where all information in a certain category is exempt from publication, and harm based, where the release of specific information may have negative consequences. Absolute exemptions of most relevance to national security operations relate to 'bodies dealing with security matters', information in court records and information that could prevent the 'effective conduct of public affairs'. Meanwhile, class based qualified exemptions of relevance include national security information not covered by the absolute exemption and information related to 'government policy', communications and legal advice. Relevant harm based exemptions relate to, among other themes, 'international relations' or information that may 'inhibit the free and frank provision of advice or exchange of views' (UK Ministry of Defence 2012). Reflecting the USFOIA, the UKFOI should not be used to hide evidence of illegality or prevent embarrassment. Indeed, UKFOI legislation states that anyone who 'alters, defaces, blocks, erases, destroys or conceals any [relevant] record $[\ldots]$ with the intention of preventing $[\ldots]$ disclosure $[\ldots]$ of the information to [...] which the applicant would have been entitled' is 'guilty of an offence' (UK Parliament 2000). That said, the UKFOI also contains an executive veto, which has, for instance, been used to stop the release of cabinet minutes on the 2003 invasion of Iraq, that allows ministers to overrule the Information Commissioner, who hears appeals against UKFOI refusals, and prevent the release of documents. Thus creating the potential for 'exceptional secrets' that can 'undermine the foundations upon which legitimate liberal democratic state secrets are validated' (Thomas 2019, 14). 
The compound effect of the UK's information control system and the UKFOI can have significant impacts on oversight. During their late $20^{\text {th }}$ Century engagement in Northern Ireland, for instance, UK forces provided weaponry and intelligence information to loyalist paramilitaries that contributed to the killing of innocent civilians (Cadwallader 2013). A joint report from Queen's University, Belfast, and the Committee on the Administration of Justice on the continued effect of official policies in perpetuating impunity for such crimes highlights three ways UK classification and declassification systems may help perpetuate impunity. Firstly, the report notes the overclassification of documents as top secret has led to additional delays to subsequent investigations and public inquiries and has 'inhibit[ed] the sharing of relevant material'. Per the report, these delays arose from the increased protocols related to material classified as top secret. Secondly, the report argues the UKFOI public interest test has been interpreted too liberally, leading to over redaction. Finally, the report critiques the UK state's attempts to gain 'blanket anonymity' for UK agents giving evidence, stating this has limited the effectiveness of contemporary investigations (Committee on the Administration of Justice and Queens University Belfast 2015, 14).

Collectively, the report from Queen's University and the Committee on the Administration of Justice and the treatment of information related to Guantánamo illuminate how different facets of information control systems can, in conjunction, become tools that, deliberately or otherwise, may prevent the release of information via legitimate channels of public inquiry. Thereby restricting the ability of those attempting to use freedom of information processes as a mediating tool. In the UK, for instance, overclassification of the type identified by Arendt created obstacles that led to practical barriers to dissemination. Whilst, the potentially overzealous interpretation of the UKFOI public interest test has likely prevented information from becoming public. It could be 
argued this is not a fault with the legislation, but of those implementing it. One could also contend redacted information was withheld legitimately. Yet, if information that should not have been classified as top secret was thus labelled, then the application of the public interest test to such information would probably have been more burdensome than if the same information had a lower classification level: thus, by illuminating the compound costs of classification and constraints on information operating concurrently, reflecting the picture painted by Donohue. Finally, the ability of the UK state to insist on the anonymity of state agents illustrates that barriers and impediments to the release of information do not just relate to historical events and documents pertaining to them, but can relate to contemporary proceedings and individuals involved in them. Returning to the US, the treatment of information (as well as a double secret type failure to even acknowledge if such information exists) about Guantánamo detainees illuminates similar barriers and impediments exist for those seeking information about the site. With these similarities in mind, this paper turns to its two case-studies: USFOIA requests, and subsequent legal processes, placed by the American Civil Liberties Union (ACLU) related to those held by the US during the War on Terror and responses to UKFOI requests placed by the UK All Party Parliamentary Group (APPG) on Extraordinary Rendition related to the UK's role in the post-9/11 US rendition system.

\section{Freedom of Information Case-Studies}

Per the democratic oversight narrative, USFOIA and UKFOI processes should, as tools of mediation, help prevent unjustified secrecy. Yet, as we have seen, reality does not always match up with the ideals captured by the democratic oversight narrative. Especially if one considers USFOIA and UKFOI processes in conjunction with broader information control systems. Reflecting this, the two case-studies engaged with below further evidence tools that can be used by US and UK governments to stem the release of 
potentially implicatory information. As a result, important similarities are documented which, together, provide evidence of harms related to the in-security of non-disclosure, compound those identified in the previous two sections and, arguably, illustrate a potential push back against the trend towards openness identified by Aldrich and Moran. All told, these case-studies evidence three interrelated harms. Firstly, former detainees, and their families and representatives, are deprived of information pertaining to mistreatment. As are those engaged in oversight, whether internal or ambient. Finally, the combination of political game-playing and the deployment of discursive tropes present in both instances will likely undermine faith in government assertions and policies moving forward.

\section{American Civil Liberties Union Freedom of Information Requests}

In October 2003, six months before the Abu Ghraib scandal broke, the ACLU logged an USFOIA request for documentation pertaining to 'the treatment, death, and rendition' of US detainees held abroad (American Civil Liberties Union 2018). After the US government failed to fulfil the request, the ACLU filed suit. In September 2004, Judge Alvin Hellerstein of the Southern District Court of New York ordered the release of documents pertaining to the request (American Civil Liberties Union 2018). As a result, thousands of, often partly redacted, documents related to closed US military investigations into the abuse and death of detainees held in Iraq, Afghanistan and Guantánamo have been released. Though the release of these documents is welcomed, as we shall see, the ability of the US government to control the release of certain documents, and the potential subversion of a legitimate safeguard to prevent the release of others, demonstrates probable limits in the USFOIA's utility as a mediating tool.

For documents to be released under Hellerstein's ruling, they needed to relate to closed cases. Within Iraq, from July 2004 to the end of 2005, closing cases was, in theory, 
the responsibility of the Detainee Abuse Task Force. A body set up to investigate 'allegations of Iraqi detainee abuse involving coalition forces' (US Army Criminal Investigation Command 2004). Nevertheless, suspicions developed amongst task force personnel that their superiors were keeping cases open to prevent them being subject to the ruling. Jon Renaud, a task force commander, for instance, states; '[w]e'd close it and bam! — they'd kick it back to us', political game-playing he felt was 'borderline illegal' (Renaud in Phillips 2011). Likewise, Angela Birt, who oversaw US military police operations in Iraq, including the task force, claims she considered the possibility her superiors were 'sending [...] [cases] back because', if open, they were 'not subject to [US]FOIA' (Birt in Phillips 2011). As such, Renaud and Birt highlight the possibility a legitimate safeguard, that documentation pertaining to open cases should not be released, was manipulated to prevent the release of information that should have legitimately been in the public domain.

As well as potentially illegitimately re-opening cases, the US government has, despite continual judicial rulings to the contrary, stemmed the release of over 2,000 photographs subject to the ACLU request. Among other abuses, the photos allegedly show a soldier 'posing as if [she] was sticking the end of a broom stick into' a detainee's 'rectum' and a teenager following a 'mock execution' (Relman 2015). Hellerstein ordered at least the photographs' partial release in 2005 and 2006, as did an appeals court in 2008 (Hellerstein 2014, 1; US Defense Department 2009, 2). Initially, the US government agreed to acquiesce to the 2008 judgement (US Defense Department 2009, 2). Yet, the photographs' release was stymied by the passing of the Protected National Security Documents Act, which gave the Defense Secretary the ability to prevent the release of 'protected documents' if they felt release would 'endanger' US citizens, military personnel or government employees based abroad. The act labels all photographs subject 
to the ACLU USFOIA request protected documents (US Congress 2009). Both George W. Bush and Barack Obama, along with senior military commanders, argued the photographs' release would be counterproductive, and place US 'troops in danger' (Obama in Walker 2014; Odierno 2009; Petraeus 2009).

In 2009, drawing on the Protected National Security Documents Act, Defense Secretary Robert Gates blocked the photographs' release (Gates, R. 2009, 4a-5a). In 2012, Gates' successor, Leon Panetta, re-certified this position (American Civil Liberties Union 2014, 1). However, in August 2014 Hellerstein found the re-certification was 'not sufficient to prevent' publication as it treated the photographs 'as a single body of evidence' instead of justifying 'the withholding of each photograph' (Hellerstein 2014, 2). In February 2015 Hellerstein gave the US government until March $17^{\text {th }} 2015$ to provide individual justifications, stating that if this did not occur his August 2014 judgement would be filed, causing the photographs' release (Hellerstein 2015, 2-3). The US government asked for the judgement's deferral, but did not submit individual justifications, leading Hellerstein to order the release of 'all' the photographs on March $20^{\text {th }} 2015$ (Hellerstein 2015a, 1). Faced with this ruling, the US government selected and released 198 photographs in February 2016 (Akerman 2016). Among other things, the released photographs show hooded and blindfolded detainees and injuries of a detainee who was 'detained, tortured, and killed by U.S. forces' in November 2003 in Iraq (Relman 2016; US Defense Department 2016, 1-162,1-3,16,30). The US government selected the photographs it released, leading the ACLU's Alex Abdo to suspect those released are the 'most innocuous' (Abdo in Akerman 2016). The ACLU continues to pursue the release of the remaining photographs (Akerman 2016; American Civil Liberties Union 2017).

Across two presidential administrations from opposing political parties, the reigns of successive defense secretaries and facilitated by senior military figures, the treatment 
of the ACLU's USFOIA request provides evidence of the wide-ranging tools the US government has at its disposal to influence the release of information that, per numerous judicial rulings, should be public. If true, the political game-playing represented by the re-opening of cases to deliberately stall the release of documents is a legitimate safeguard's clear perversion. Similarly, the use of the judicial system to stop, or at least stall, the release of documents pertaining to detainee abuse, as well as the passing of the Protected National Security Documents Act, which itself provided Gates and Panetta a new layer of policies and protocols with which to frame narratives of the photos via discursive tropes centred on the security Vs freedom rubric, illustrate the wide ranging nature of tools available to the US government to stem the release of information and how such tools can evolve in real time. Moreover, the fact less than $10 \%$ of the photographs subject to the ACLU USFOIA request, which have consistently been ordered released, are currently in the public domain encapsulates the US government's capacity to resist judicial oversight. Something further exemplified by its selection of which photographs should be released. Correspondingly, though the nuances of the UKFOI process differ, it is now shown that the UK government has been similarly able to stall the release of information subject to UKFOI requests.

\section{All Party Parliamentary Group Freedom of Information Requests}

In 2008 Ben Griffin, a former SAS member, alleged detainees captured by UK personnel were transferred to US custody, mistreated and rendered out of Iraq. The UK government took out an injunction against Griffin to prevent him revealing further information (Norton-Taylor 2008). In response, between 2008-2011 the APPG on Extraordinary Rendition, then chaired by Andrew Tyrie MP, submitted UKFOI requests related to Griffin's claims (UK Administrative Appeals Chamber 2011,3). These requests caused reviews by UK Defence Secretary, Des Browne MP, and Lieutenant General 
Lamb, UK Field Army Commander. Browne found 'no evidence' detainees 'captured by' UK personnel and later held by the US were abused or 'unlawfully' rendered (Browne 2008). Similarly, in a report, released in redacted form following further UKFOI requests, Lamb voiced 'no concerns', with the UK said to be meeting its 'obligations' via 'assurances, operational judgement and record keeping' (Browne 2008a; Browne 2008b; Tyrie 2008) The redacted report showed the review occurred from March 4th- $7^{\text {th }} 2008$, took 48 hours and was a 'rapid audit of current practice' followed by 'a short period of policy and [a] legal audit' (Browne 2008b). Despite its 'rapid' nature and contemporaneous focus, Browne engaged in an apparent discursive sleight of hand by pointing to the review as evidence the UK was meeting its 'legal obligations' when responding to questions about detainees captured earlier in the conflict (Browne 2008c). However, in February 2009 Browne's successor as Defence Secretary announced a third review had found evidence of the rendition to Afghanistan of two UK detainees (Hutton 2009, 2009a). It was later confirmed these detainees were captured by UK Special Forces and transferred to US custody at Abu Ghraib prior to rendition to Afghanistan, whilst legal documents detail abuse by UK and US personnel (Leigh Day 2014; Reprieve 2017). In short, not only did the renditions occur, but Browne and Lamb both completed flawed reviews that allowed Browne to state publicly no detainees captured by UK personnel and transferred to US custody were rendered from Iraq.

When seeking information, the APPG was faced with a variety of barriers and impediments. In one response, for instance, Browne cited the neither confirm nor deny policy, and, mirroring the US Glomar response, asserted this citation was not 'conclusive evidence' said information 'exists or does not exist' (Browne 2008c). Countering Browne, the APPG argued the 'serious and credible' nature of Griffin's allegations provided 'a basis for a [policy] deviation' (Tyrie 2008a). While the neither confirm nor 
deny policy's parameters are debateable, UKFOI timeframe response rules are clear. Nevertheless, an internal review of Ministry of Defence procedures sought by the APPG was sent 87 days late (Tyrie 2009). Elsewhere, questions were (deliberately?) misinterpreted. Responding to a Parliamentary question querying whether anyone 'captured by British forces' in Iraq and Afghanistan had later been detained at 'Guantanamo Bay'? Browne stated the US and the UK had an 'understanding' such detainees 'cannot be removed from the country without [...] [UK] agreement' and that the UK had not consented to any detainee transfers to Cuba. Responding, Tyrie noted this was 'not an answer' to his 'question' (Tyrie 2007). Finally, Tyrie was offered at least three briefings on privy Council terms (Browne 2008a, 2008c). Such briefings allow MPs to be briefed on information the UK government deems sensitive but prevents them sharing it, thus restricting its oversight value (UK Cabinet Office 2011, 9). Indeed, an appeals court judgement (discussed below) found, the APPG members, by placing UKFOI requests, were acting as 'concerned citizens' and not MPs 'entitled to information on confidential Privy Councillor terms', making the offer inappropriate in this instance (UK Administrative Appeals Chamber 2011, 7).

Faced with these barriers and impediments the APPG appealed to the Information Commissioner, who in 2010, in the judgement that led to the release of Lamb's name, ruled in favour of a partial release of documents. This judgement satisfied neither the APPG nor the Ministry of Defence, and their appeals were combined (UK Administrative Appeals Chamber 2011, 6). In 2011, an appeals court ordered the further partial release of documents, including a 2003 UK, US and Australian detention operations Memorandum of Understanding and the un-redacted Lamb review (UK Administrative Appeals Chamber 2011, 3). Significantly, the memorandum stated detainee 'transfers' would be 'recorded' and the removal from Iraq 'of transferred' detainees would 'only be 
made' with 'the mutual arrangement' of the detaining and accepting states (Australian Government, UK Government and US Government 2003). Given neither Browne or Lamb uncovered evidence of the rendition to Afghanistan of the two UK Special Forces detainees, it seems likely either a 'mutual arrangement' was not sought by the US or the UK failed to fully record them. A potential reason for such a failure is contained in the un-redacted Lamb review, which states that from March 2003-June 2004, '[t]here was no [UK] requirement to track detainees' after 'handover to the US' (Lamb 2008). As such, despite an obligation to track the treatment of detainees transferred to another state arising from the Geneva conventions, for the first 15 months of the Iraq War the UK did not require such tracking for those transferred to US custody (Third Geneva Convention 1949, Art. 12; Fourth Geneva Convention 1949, Art. 45; Lamb 2008, 1). According to Tyrie, the documents 'reveal many of the circumstances which allowed' UK involvement in, and complicity with, renditions from Iraq (All Party Parliamentary Group on Extraordinary Rendition 2011).

Starting with the injunction against Griffin, moving through the flawed Browne and Lamb reviews (and the discursive sleight of hand they engendered), allusions to the neither confirm nor deny policy, the failure to follow the UKFOI's time specifications, the appealing of the information commissioner's judgement, the game-playing represented by the misinterpretation of parliamentary questions and the offering of privy briefings, the list of barriers and impediments faced by the APPG on Extraordinary Rendition appears overly burdensome. Although many of the tools drawn on by the UK government may be legitimate safeguards within the UKFOI process, collectively they exemplify the ability of the UK state to dilute the effect of, or, at least, stall the consequences of, UKFOI requests. Indeed, this list appears to lend weight to Weber's warnings about informational asymmetry between government bureaucracies and 
politicians. Furthermore, whilst the APPG had institutional cachet arising from its parliamentary affiliation, it is doubtful many private individuals would have the resources to pursue requests across a four-year period when faced with such a list.

Given the prominence placed on open government within the democratic oversight narrative, the reactions of the US and UK governments to freedom of information requests detailed above is problematic. While documents were eventually released by both states, these releases materialised only after significant time and resources were ploughed into judicial cases by the ACLU and the APPG on Extraordinary Rendition. In essence, though attempts by both states to prevent the release of implicatory information can be fought, those with the resources to do so are likely to be limited. Moreover, the fact the US is still to release over 90 percent of the photographic content related to a USFOIA request placed over 15 years ago, despite being continually ordered to do so, illustrates that, in the US at least, judicial oversight of freedom of information requests has its limitations and highlights that, as has happened in the UK in the context of Northern Ireland, barriers to the release of information supposedly subject to freedom of information requests can continue long after operations end.

All told, three interrelated harms arise from the above case-studies. Firstly, former detainees who have been mistreated, and their families and representatives, are deprived of information about their mistreatment. In a UK context, this harm may become more acute if proposals put forward by successive Defence Secretaries to create a 'statutory presumption against prosecution' of UK military personnel beginning a decade after an event has occurred become law (Sabbagh 2019). Potentially creating a system where 
lengthy delays and deferrals to policies and protocols could, deliberately or otherwise, run down the clock on the possibility of punishment for illegality. Given that, as of July 2019, investigations into the conduct of UK personnel in Iraq from 2003-2009 were ongoing, this is a live issue rather than a hypothetical point (Service Police Legacy Investigations 2019). Secondly, others engaged in oversight, whether internal or ambient, are similarly deprived of information. This could have real world effects if flawed proposals based on needlessly incomplete information are adopted by policy makers. Finally, facets of the above case-studies, such as the perfunctory and ultimately flawed Browne and Lamb reviews, the game-playing represented by the miss-answering of questions and the potential manipulation of a legitimate safeguard and the continual failure of the US government to abide by judicial rulings, are likely to undermine faith in official assertions and actions moving forward. Indeed, as Alex Abdo of the ACLU has noted when discussing the re-opening of Detainee Abuse Task Force investigations, '[i]f it is true that the government deliberately reopened investigations for no other purpose than to avoid transparency [...], that conduct is nothing short of outrageous' and would violate the '[US]FOIA and the government's obligations of transparency' (Abdo in Phillips 2011).

\section{Conclusion}

Legitimate debates exist about how much information states should hold and release. Furthermore, once held, safeguards to regulate the release and mediation of information are obviously required. Such safeguards should clearly include those designed to prevent the release of documents pertaining to open investigations of detainee abuse. Yet, as illustrated, such safeguards can be manipulated in a manner that allows states to stem the release of information that should legitimately be released. Indeed, the ability of the US and the UK to exploit their structural influence to dilute the effect of 
oversight tools (sometimes by deploying tools at their own disposal, sometimes by conspicuously doing nothing), is substantial. With the ability to ignore the time limits set by freedom of information legislation and to only partially fulfil such requests even after judicial rulings in favour of their fulfilment have occurred, being symptoms rather than causes of this influence. Furthermore, this paper has illustrated that, in the case of both states, freedom of information processes can only be truly understood as part of broader information classification and control systems, with the categories and processes of these broader systems affecting what information is released. Given that freedom of information is a tool available to all those engaging in oversight, the compounding effect of these broader information classification and control systems is particularly important to comprehend. Especially when reflecting on the ability of freedom of information processes to contribute to the ideals captured by the democratic oversight narrative.

Recent scholarship has argued that practices of state secrecy are providing declining returns. Given the effects of headline grabbing whistle-blowers, this conclusion appears sound. Yet, the ability of the US and the UK to push-back against the freedom of information requests lodged by the ACLU and the APPG on Extraordinary Rendition suggests, perhaps, that, both states are adapting to the new challenges to their control of potentially implicatory information, especially when those seeking information are prepared to operate within the strictures of state mandated processes. Moreover, this adaption appears to illustrate some of the harms not captured by the security Vs freedom rubric, with the ACLU and other interested parties, for instance, unable to engage in the analysis and discussion of photographic material related to the ACLU USFOIA request that courts have ordered released. More to the point, we have seen how such processes, such as privy briefings, could be used to bring those seeking greater openness into the fold and, thus, potentially neutering attempts at (democratic) oversight. In short, the two 
case-studies reviewed above, as well as the material covered in this article's first three sections, suggest the administration of freedom of information requests pertaining to US and UK national security operations are, as a result of overly burdensome barriers and impediments, not always dealt with in a manner that would live up to the standards captured by the idealised version of the democratic oversight narrative. A picture that, the evidence reviewed above suggests, also appears to be the case for other tools of mediation.

\section{References}

Ackerman, J.; Sandoval-Bellesteros, I. 2006. 'The Global Explosion of Freedom of Information Laws." Administrative Law Review. 58 (1). 85-130. url: https://www.jstor.org/stable/40712005

Akerman, S. 2016. Nearly 200 Images Released by US Military Depict Bush-era Detainee Abuse. The Guardian, February 28. Accessed August 142018. http://www.theguardian.com/us-news/2016/feb/05/us-military-bush-era-detainee-abusephotos-released-pentagon-iraq-afghanistan-guantanamo-bay?CMP $=$ share btn tw

Aldrich, R.; Moran, J. 2018. "'Delayed Disclosure': National Security, WhistleBlowers and the Nature of Secrecy" Political Studies. 1-18. url: https://doi.org/10.1177/0032321718764990

Aldrich, R.; Richterova, D. 2018. ' Ambient Accountability: Intelligence Services in Europe and the Decline of State Secrecy.' West European Politics. (41) 4. 1003-1024. doi: https://doi.org/10.1080/01402382.2017.1415780

All Party Parliamentary Group on Extraordinary Rendition. 2011. Press Release. 22 June 2011. Accessed February 2017.

http://www.extraordinaryrendition.org/documents/send/6-2011/86-foia-press-release22-06-11.html

American Civil Liberties Union. 2014. Memorandum in Support of Plaintiffs' Seventh Motion for Partial Summary Judgement in US Department of Defence V ACLU.

American Civil Liberties Union. 2017. ACLU V Department of Defense. Accessed July 11 2017. https://www.aclu.org/cases/aclu-v-department-defense

American Civil Liberties Union. 2018. The Torture Database: Background. Accessed June 11 2018. https://www.thetorturedatabase.org/about

Arendt, H. 1973. Crises of the Republic. Harmodsworth: Pelican. 
Australian Government; UK Government and US Government. 2003. Arrangement for the Transfer of Prisoners of War, Civilian Internees, and Civilian Detainees.

Ball, C. 2009. '’What is Transparency?', Public Integrity. (11) 4. 293-307. url: https://www.tandfonline.com/doi/abs/10.2753/PIN1099-9922110400

Bennett, W.; Lawrence, R.; Livingston, S. 2005. 'None Dare Call it Torture.' Journal of Communication. (56) 3. 467-485. doi: https://doi.org/10.1111/j.1460$\underline{2466.2006 .00296 . x}$

Birkinshaw, P. 2010.' 'Freedom of Information and Its Effect on the UK.' Government Information Quarterly. (27) 4. 312-321. doi: https://doi.org/10.1016/i.giq.2010.06.006

Blakeley, R.; Raphael, S. 2017. ''British Torture in the 'War on Terror'.' European Journal of International Relations. (23) 1. 243-266. Doi: https://doi.org/10.1177/1354066116653455

Box, S. 1989. Secrets. New York, NY.: Vintage Books.

Brake, T. 2016. The Freedom of Information Act has Just One Problem: It Doesn't Go Far Enough. New Statesman. January 16. Accessed August 122018. https://www.newstatesman.com/politics/staggers/2016/01/freedom-information-act-hasjust-one-problem-it-doesnt-go-far-enoughV

Browne, D. 2008. 19 $9^{\text {th }}$ March Freedom of Information Request Response Letter to Andrew Tyrie.

Browne, D. 2008a. $7^{\text {th }}$ July Freedom of Information Request Response Letter to Andrew Tyrie.

Browne, D. 2008b. $7^{\text {th }}$ July Freedom of Information Request Response Letter to Andrew Tyrie. Attachment A: Redacted Version of the Review of Detention Practices in Iraq and Afghanistan.

Browne, D. 2008c. $5^{\text {th }}$ September Freedom of Information Request Response Letter to Andrew Tyrie.

Cadwallader, A. 2013. Lethal Allies: British Collusion in Ireland. Cork: Mercier Press.

Colaresi, M. 2014. Democracy Declassified. Oxford: Oxford University Press.

Committee on the Administration of Justice and Queens University Belfast 2015. The Apparatus of Impunity? Human Rights Violations and the Northern Ireland Conflict. Accessed May 302016.

http://www.caj.org.uk/files/2015/01/30/No._66 The_Apparatus_of_Impunity_Human_r ights_violations and the Northern_Ireland_conflict,_Jan_2015_1.pdf

Curtin, D.; Meijer, A. 2006. Does Transparency Strengthen Legitimacy? A Critical Analysis of European Union Policy Documents. Information Polity. (11) 2. 109-122. url: https://dl.acm.org/citation.cfm?id=1412570 
Curtin. D 2014 'Overseeing secrets in the EU: A democratic perspective." Journal of Common Market Studies. (52) 3. 684-700. doi: https://doi.org/10.1111/jcms.12123

Deeks, A. 2013. ' The Observer Effect: National Security Litigation, Executive Policy Changes, and Judicial Deference.' Fordham Law Review. (82) 2. 827-898. url: https://ir.lawnet.fordham.edu/flr/vol82/iss2/16/

Defty, A. 2019. When will the government respond to the Intelligence and Security Committee's report on UK lethal drone strikes in Syria?. Accessed July $8^{\text {th }} 2019$. http://www.democraticaudit.com/2019/04/26/when-will-the-government-respond-to-theintelligence-and-security-committees-report-on-uk-lethal-drone-strikes-in-syria/

Defty, A. 2019a. ' Coming in from the Cold: Bringing the Intelligence and Security Committee into Parliament." Intelligence and National Security. (34) 1. 22-37. doi https://doi.org/10.1080/02684527.2018.1513441

Denham, E. 2018. Trust, Transparency and Just-in-Time FOI: Sustainable Governance and Openness in the Digital Age. Accessed August 12 ${ }^{\text {th }}$ 2018. https://ico.org.uk/aboutthe-ico/news-and-events/news-and-blogs/2018/03/trust-transparency-and-just-in-timefoi-sustainable-governance-and-openness-in-the-digital-age/

Donohue, L. 2008. The Cost of Counterterrorism: Power, Politics, and Liberty. Cambridge: Cambridge University Press.

Electrospaces. 2013. The US Classification System. Accessed October 132016. http://electrospaces.blogspot.co.uk/2013/09/the-us-classification-system.html

Feinberg, L. 2004. 'FOIA, Federal Information Policy, and Information Availability in a Post-9/11 World.' Government Information Quarterly. (21) 4. 439-460. doi: https://doi.org/10.1016/i.giq.2004.08.004

\section{Fourth Geneva Convention. 1949.}

Fox, R. 2013. Ten Years After Iraq: 'Illusion of Consensus' that Sent us to War. This Week. March 18. Accessed July 3 2015. http://www.theweek.co.uk/world-news/iraq2003/52065/iraq-war-anniversary-illusion-syria

Galison, P. 2004. 'Removing Knowledge.' Critical Inquiry. (31) 3. 229-243. url: https://www.jstor.org/stable/10.1086/427309

Gates, R. 2009. Certification of the Secretary of Defence. In US Department of Defence (2009) Supplemental Brieffor Petitioners in US Department of Defence V ACLU.

Gill, P.; Phythian, M. 2018. Intelligence in an Insecure World. Third Edition. Cambridge: Polity.

Gurria, A. 2016. Openness and Transparency - Pillars for Democracy, Trust and Progress. Accessed August 13 2016. http://www.oecd.org/about/secretarygeneral/opennessandtransparency-pillarsfordemocracytrustandprogress.htm 
Hellerstein, A. 2014. Judgement in US Department of Defence V ACLU.

Hellerstein, A. 2015. Order Clarifying Instructions for Defendants Submissions in US Department of Defence $V A C L U$.

Hellerstein, A. 2015a. Order Granting Judgement for Plaintiff in US Department of Defence $V A C L U$.

Hutton, J. 2009. Statement to the Houses of Parliament: Records of Detention (Review Conclusions).

Hutton, J. 2009a. 26 ${ }^{\text {th }}$ February Freedom of Information Request Response Letter to Andrew Tyrie.

Institute for Democracy and Electoral Assistance. 2014. Democracy and the Post-2015 Development Agenda: The Importance of Transparency and Accountability in Service Delivery.

Johnson, L. 2018. Spy Watching: Intelligence Accountability in the United States. Oxford: Oxford University Press.

Joseph, R. 2011. The War Prerogative: History, Reform, and Constitutional Design. PhD thesis submitted to Oxford University.

Karlshoej-Pedersen, M.; Walpole, L. 2018. Britain's Shadow Army: Policy Options for External Oversight of UK Special Forces. Remote Warfare Report.

Kelly, T. 2012. This Side of Silence: Human Rights, Torture and the Recognition of Cruelty. Philadelphia, PA.: University of Pennsylvania Press.

Kitrosser, H. 2008. ' 'Congressional Oversight of National Security Activities:

Improving Information Funnels.' Cardozo Law Review. (29) 3. 1049-1090. url:

https://scholarship.law.umn.edu/cgi/viewcontent.cgi?article $=1090 \&$ context=faculty arti $\underline{\text { cles }}$

Lamb, G. 2008. Detention Practices in Iraq and Afghanistan.

Leigh Day. 2014. Re-Amended Particulars of Claim in Yunus Rahmatullah v The Ministry of Defence and The Foreign and Commonwealth Office.

Lewis, D. 2013. Zero Six Bravo Proves that Too Much Secrecy Over Special Forces is a Bad Thing. Spectator. April 3. Accessed August 222018.

https://blogs.spectator.co.uk/2013/04/zero-six-bravo-proves-that-too-much-secrecyover-special-forces-is-a-bad-thing/

Manin, B.; Przeworski, A.; Stokes, C. 1999. 'Introduction.' In Manin, B.; Przeworski, A.; Stokes, C. (eds) Democracy, Accountability, and Representation. 1-26. Cambridge: Cambridge University Press. 
Maravall, J.; Przeworski, A. 2003. 'Introduction.' In Democracy and the Rule of Law, edited by Maravall, J. and Przeworski, A., 1-14. Cambridge: Cambridge University Press.

McCormack, W. 2014. U.S. Judicial Independence: Victim in the 'War on Terror'. Washington and Lee Law Review. (71) 1. 305-402. url:

https://scholarlycommons.law.wlu.edu/cgi/viewcontent.cgi? article $=4374 \&$ context $=$ wlul $\underline{\mathrm{r}}$

Meyerowitz, S. 2008. 'Gloomy Glomar Ruling.' Privacy \& Data Security Law Journal. July/August. 735-750. url:

https://www.meyerowitzcommunications.com/pdf/Gloomy\%20Glomar\%20Ruling.pdf

MI5. 2015. Policy on Disclosure. Accessed August 2015.

https://www.mi5.gov.uk/home/about-us/who-we-are/mi5-history/mi5---the-authorisedcentenary-history/centenary-history---policy-on-disclosure.html

Norton-Taylor, R. 2008. Court Gags Ex-SAS Man Who Made Torture Claims. The Guardian. February 29. Accessed August 222018.

https://www.theguardian.com/uk/2008/feb/29/military.law

Norton-Taylor, R. 2014. Why 'Neither Confirm nor Deny' has become Untenable for British Spies. The Guardian. Accessed August 222018.

http://www.theguardian.com/commentisfree/2014/jul/15/neither-confirm-nor-denybritish-spies-edward-snowden-revelations

Odierno, R. 2009. Unclassified Redacted Declaration of General Raymond T. Odierno. In US Defense Department Motion to Recall the Mandate in US Department of Defence $V A C L U$.

Mann, T.; Ornstein, N. 2006. 'When Congress Checks Out.' Foreign Affairs. (85) 6. 67-82. url: https://www.foreignaffairs.com/articles/united-states/2006-11-01/whencongress-checks-out

Petraeus, D. 2009. Unclassified Redacted Declaration of General David H. Petraeus. In US Defense Department Motion to Recall the Mandate in US Department of Defence $V$ $A C L U$.

Phillips, J. 2011. Inside the Detainee Abuse Task Force. The Investigative Fund. May 13. Accessed August 222018.

http://www.theinvestigativefund.org/investigations/iraqafghanistan/1495/inside the det ainee abuse task force/?page $=$ entire

Rejali, D. 2007. Torture and Democracy. Kindle Edition. Princeton, NJ. Princeton University Press.

Relman, E. 2015. A Picture of Torture Is Worth a Thousand Reports. ACLU. April 18. Accessed August 20 2018. https://www.aclu.org/blog/speak-freely/picture-tortureworth-thousand-reports 
Relman, E. 2016. The Stories Behind the Government's Newly Released Army Abuse Photos. ACLU. February 11. Accessed August 202018.

https://www.aclu.org/blog/speak-freely/stories-behind-governments-newly-releasedarmy-abuse-photos

Remick, D. 2004. ' Introduction.' In Chain of Command, Hersh, S. IX-XIX. London: Penguin.

Reprieve. 2017. Yunus Rahmatullah. Accessed August 32017. http://www.reprieve.org.uk/case-study/yunus-rahmatullah/

Sabbagh, D. 2019. Mordaunt Hints at Amnesty for Historical Actions by UK Soldiers. The Guardian. Accessed July 92019.

https://www.theguardian.com/politics/2019/may/09/mordaunt-hints-at-amnesty-forhistorical-actions-by-uk-soldiers

Sagar, R. (2013) Secrets and Leaks. Oxford. Princeton University Press.

Shapiro, I. 2003. The Moral Foundations of Politics. London: Yale University Press.

Service Police Legacy Investigations. 2019. Guidance. Accessed July 112019. https://www.gov.uk/guidance/service-police-legacy-investigations

Third Geneva Convention. 1949.

Thomas, O. D. 2019. Security in the balance: How Britain tried to Keep its Iraq War Secrets. Security Dialogue. doi: https://doi.org/10.1177/0967010619839544

Truman, H. 1951. Executive Order 10290.

Tyrie, A. 2007. $19^{\text {th }}$ December Letter to Des Browne.

Tyrie, A. 2008. 20 $0^{\text {th }}$ June Freedom of Information Request Letter to Des Browne.

Tyrie, A. 2008a. $21^{\text {st }}$ October Letter to John Hutton.

Tyrie, A. 2009. $22^{\text {nd }}$ April Letter to Information Commissioner Richard Thomas.

Tyrie, A. 2010. $6^{\text {th }}$ October Freedom of Information Request to Liam Fox.

UK Administrative Appeals Chamber. 2011. All Party Parliamentary Group on Rendition V Information Commissioner \& Ministry of Defence.

UK Cabinet Office 2011. The Cabinet Manual.

UK Cabinet Office 2013. Government Security Classifications April 2014.

UK Cabinet Office 2014. Government Security Classifications April 2014. 
UK Cabinet Office 2018. Government Security Classifications April 2014: Version 1.1 May 2018.

UK Information Commissioner's Office. 2019. What should we do when we receive a request for information?. Accessed 16 July 2019. https://ico.org.uk/fororganisations/guide-to-freedom-of-information/receiving-a-request/

UK Intelligence and Security Committee. 2019. About the Committee. Accessed 13 February 2019. http://isc.independent.gov.uk/

UK Judicial Office. 2015. Independence. Accessed July 112015.

https://www.judiciary.gov.uk/about-the-judiciary/the-judiciary-the-government-and-theconstitution/jud-acc-ind/independence/

UK Ministry of Defence. 2012. Compliance Notes: FOI Exemptions.

UK Parliament. 1989. Security Service Act.

UK Parliament. 1994. Intelligence Services Act.

UK Parliament. 2000. Freedom of Information Act 2000.

US Geospatial Intelligence Foundation. 2016. 2016 State of GEOINT Report. Accessed August 13 2016. http://usgif.org/system/uploads/4510/original/2016_SoG_book.pdf

US Army Criminal Investigation Command. 2004. August $17^{\text {th }} 2004$ Detainee Abuse Task Force: Request for Assistance.

US Congress. 2009. Protected National Security Documents Act.

US Defense Department. 2009. Motion to Recall the Mandate in US Department of Defence $v$ ACLU.

US Defense Department. 2013. Special Access Program (SAP) Security Manual: Marking.

US Defense Department. 2016. ACLUv DOD FOIA Abuse Photos: February 2016 Release.

US Department of Homeland Security. 2006. Sensitive Security Information (SSI).

US Justice Department. 2015. Learn. Accessed October 302015.

http://www.foia.gov/about.html

US Justice Department. 2015a. What is FOIA?. Accessed October 302015.

http://www.foia.gov/

US Justice Department. 2015b. Frequently Asked Questions. Accessed October 30 2015. http://www.foia.gov/faq.html 
US Government 1982. Code of Federal Regulations: 18 CFR 3a.11 - Classification of official information. Accessed October 302015.

https://www.law.cornell.edu/cfr/text/18/3a.11

US Government. 1984. Title 50 US Code: 3141 - Operational files of the Central Intelligence Agency. Accessed May 272016.

https://www.law.cornell.edu/uscode/text/50/3141

US Government. 2015. Code of Federal Regulations: 22 CFR 9.4 - Original classification. Accessed October 30 2015. https:/www.law.cornell.edu/cfr/text/22/9.4

US Under Secretary of Defense. 2005. Use of the 'Not Releasable to Foreign Nationals' (NOFORN) Caveat on Department of Defense (DOD) Material.

Vincent, B. 1998. The Culture of Secrecy: Britain, 1832-1998. Oxford: Oxford University Press.

Wagner, A. 2017. ''Essential or Extravagant: Considering FOIA Budgets, Costs and Fees." Government Information Quarterly. (34) 3. 388-395. doi: https://doi.org/10.1016/i.giq.2017.09.001

Walker, L. 2014. Remember the Abu Ghraib Torture Pictures? There are more that Obama Doesn't Want You to See. Newsweek. October 22. Accessed August 222018. http://europe.newsweek.com/remember-abu-ghraib-torture-pictures-there-are-moreobama-doesnt-want-you-see-279254?rm=eu

Weber, M. 2009. From Max Weber: Essays in Sociology. Edited by H.H. Gerth and C. Wright Mills. Oxon: Routledge.

Worthington, A. 2011. Abu Zubaydah and the Silencing of Guantánamo's "High-Value Detainees," as the CIA Censors His Drawings. October 10. Accessed August 222018. http://www.andyworthington.co.uk/2011/10/09/abu-zubaydah-and-the-silencing-ofguantanamos-high-value-detainees-as-the-cia-censors-his-drawings/ 